\title{
Accrediting Private Collections To Serve the Public Interest in Art
}

\author{
Andrew Toporoff* \\ INTRODUCTION
}

This Note is about the civic role of private collections of art. Specifically, it argues that private collections can and should be a fixture of the U.S. cultural landscape alongside museums, which are devoted to serving the public. ${ }^{1}$ To some extent, this already happens. Collectors often lend their artwork for museum exhibitions, for example, and some put their entire collections up for public display. ${ }^{2}$ Nothing better illustrates the convergence of owning art as an asset and for conspicuous public display than one entrepreneur's business idea to sell prefabricated private museums: Why not make it easy for collectors, with readymade galleries to accommodate the Koons or the Basquiat? ${ }^{3}$ But this Note adds to commentators who wish to see a reform in private collecting so that the public benefits more from these collections than it does currently. ${ }^{4}$

This Note argues that the public interest calls for enhancing, not subordinating, the role of private collectors. Certain commentators argue that collectors should be compelled to act in service to the public, either by lending significant works of art to a museum or publicly displaying the works themselves. ${ }^{5}$ Behind such proposals lies the notion that private collections and museums are in tension, and that museums are a superior institution for benefiting the public, if private collections are capable of

* J.D. Candidate, Columbia Law School, Class of 2021. Thank you to Professor Philippa Loengard, Columbia Law School; Marina Schneider, UNIDROIT; the editors of the Columbia Journal of Law and the Arts, especially David Fischer, Benjamin Feiner, Kate Garber, Alec Fisher, Will Reed, and Sam Smart; my parents; and Antonia Miller. I am grateful for your guidance and support.

1. See Stephen E. Weil, Breaches of Trust: Remedies and Standards in the American Private Art Museum, 2 INT'L J. Museum MGMT. \& CURATORShIP 53, 55 (1983); see also OFF. OF POL'Y \& ANALYSIS, SMithSONIAN INST., ART MUSEUMS AND THE PUBliC (2001), https://perma.cc/EN77-T7HF (identifying the principal functions of a museum as "collection, research, and public programs").

2. See infra Part II; see generally E. Alex Kirk, Note, The Billionaire's Treasure Trove: A Call To Reform Private Art Museums and the Private Benefit Doctrine, 27 FordHAM INTELL. Prop. MEdiA \& ENT. L.J. 869 (2017).

3. See Mark Ellwood, Your Own Private, Prefab Museum. Just Add Art, Wall St. J. (May 24, 2018), https://perma.cc/9JX5-AA8T.

4. See infra note 58 and Part II.A.

5. See infra Part II.

(C) 2021 Toporoff. This is an open access article distributed under the terms of the Creative Commons Attribution License, which permits unrestricted use, distribution, and reproduction, provided the original author and source are credited. 
providing public benefits at all. Informing this intuition are the legal and normative differences between private and museum ownership. Museums are subject to certain obligations that collectors do not share, the rationale for which is that they vindicate the public interest in art. ${ }^{6}$ But it does not follow from this distinction that collectors, lacking these obligations, cannot also promote the public interest through their own actions.

Private collections should play a complementary role to museums in serving the public interest. Private collections and museum collections are qualitatively different in meaningful ways. Furthermore, museums appear increasingly unable to effectively promote the public interest in art, at least without help. Thus, this Note proposes a regime that would harmonize the civic practices of collectors and museums while preserving the role of the collector. Part I explains the differences between collectors and museums with respect to ownership. One way to understand these differences is to say that while collectors mostly operate under general principles of property law, their art being their chattel, museums are subject to certain obligations on account of their charitable status and purpose. Building on the idea that these obligations exist for the benefit of the public, Part II describes how previous scholars have defined the contours of the "public interest in art" and introduces one paradigm in particular for reforming private collecting so that it serves the public interest. Part II then critiques this paradigm and shows why a different approach is necessary; in doing so, it makes an important distinction between proposals that focus on individual works of art and proposals that focus on collections in their entirety. Part III outlines an incentive-based system for achieving the desired reform under this new approach. Accrediting private collections that meet certain criteria for providing public benefits could motivate collectors to act civically and promote better practices for private collecting broadly, depending on the benefits associated with accreditation.

\section{PRIVATE VERSUS MUSEUM OWNERSHIP IN THE UNITED STATES}

Private ownership and museum ownership differ in two key respects. First, whereas collectors have no duty to care for their artwork, museums do have this duty. Second, whereas collectors can freely sell and borrow against their artwork, museums can sell only under limited conditions, and they are restricted in their ability to pledge works from their collection as collateral. ${ }^{7}$ This Part considers private

6. Patty Gerstenblith, Acquisition and Deacquisition of Museum Collections and the Fiduciary Obligations of Museums to the Public, 11 CARDOZO J. INT'L \& COMP. L. 409, 411-25 (2003) (explaining that the restrictions placed on museums are to protect the public benefit in museum access and listing the museum's primary beneficiary as the public).

7. See, e.g., Erica Orden \& Craig Karmin, Chelsea Museum Risks Losing Charter, WaLl St. J. (Aug. 10, 2010), https://perma.cc/3V64-5G4C ("The pledging as collateral of works from a museum's permanent collection is a contentious issue in cultural circles and beyond. It violates the regulations of the [New York] Education Department's Board of Regents, which supervises and grants charters to museums."). 
ownership and museum ownership to demonstrate how the public interest rationale that accounts for their differences ultimately informs the argument that collectors have a duty to provide public access to their work. In the private context, although the lack of a duty of care sometimes endangers artwork, there is a norm among collectors that collecting entails a responsibility to preserve one's art. ${ }^{8}$ At the same time, collectors' freedom of alienation does not necessarily imperil artwork, but it does make private collections likelier to be dissolved. In the museum context, both the standard of care and the restrictions on deaccessioning (that is, removing a work from a museum collection, typically by sale) are provisions that ostensibly support the public, but there is some question as to whether the museum's inability to deaccession undermines its ability to care for its art. ${ }^{9}$

\section{A. Private OWnership}

\section{Duty of Care (or Lack Thereof)}

Save for one exception, discussed below, ${ }^{10}$ collectors are not required to maintain their artwork, in terms of preservation, security, or any other form of upkeep. Although the lack of a duty of care does not necessarily imply an affirmative right to destroy, it is apt to say, as one art law manual puts it, that "an eccentric American collector who, for a Saturday evening's amusement, invited his friends to play darts using his Rembrandt portrait as the target would neither violate any public law nor be subject to any private restraint."11 Nevertheless, most collectors act as good caretakers of their art. ${ }^{12}$ There are several reasons to do this, in addition to the fact that preservation allows the collector to enjoy his or her art well into the future. One reason is monetary: A well-preserved artwork is a source of value to the collector. Another reason is legitimacy: A collector who takes poor care of his or her art will be seen as frivolous, if not worse; others will be reluctant to sell to him or her; and the collector may even be ostracized by the art community, which matters insofar as the social nature of the art world is a feature that attracts people to collecting in the first place. ${ }^{13}$ In fact, legitimate collecting contains an ethic of stewardship. As one collector expressed it: "We may have legal title when we buy [an artwork], but in a

8. See Joseph L. SAX, Playing Darts With a REMBrandT: PUBlic AND PRivate Rights IN Cultural Treasures 68 (1999).

9. See infra Part I.B.2.

10. See infra.

11. FRANKLIN FELDMAN \& StEPHEN E. Weil, ART LAW: RightS AND LiABilities OF CREATORS AND COLLECTORS 434 (1986) (quoted in SAX, supra note 8, at 1).

12. See infra note 66.

13. E.g., Christopher Glazek, The Art World's Patron Satan, N.Y. TIMES Magazine (Dec. 30, 2014), https://perma.cc/LKD5-U4EJ ("Many important galleries have blacklisted Simchowitz as a buyer" due to his collecting practices.). See also Everything You Wanted To Know About Art Gallery Ethics (But Were Afraid To Ask), New York StATE BAR Ass'N ART GAllery Ethics PANEL (Oct. 21, 2013), https://perma.cc/56BQ-PMR6 (In the panel, Richard Lehun of Stropheus Art Law explained: "[T]here are all kinds of informal discipline and methods that are exercised. Ostracism is the most popular one in the art world, to control anti-social or asocial elements."). 
moral sense, we are only stewards of the art we acquire. If well-taken care of, the artworks will survive us. So we have an obligation to do right by it." ${ }^{14}$ Some critics dismiss this description as pretentious self-flattery that provides no real instruction for care, criticism which has some merit. ${ }^{15}$ The fact remains, though, that most collectors try to be good stewards of art.

That said, a few examples of private destruction will show that a standard of care might be desirable from the perspective of the art. Fortunately, wanton destruction, like the example of the dart-throwing eccentric, is rare. More often, destruction occurs within familiar situations. Divorce is a frequent context, with stories of spouses' art being harmed or damaged during the dissolution of the marriage. ${ }^{16}$ Another context in which private art has been destroyed involves the despised portrait. A famous illustration of this is Lady Churchill's destruction of a notoriously unflattering portrait of Winston Churchill by Graham Sutherland after her husband's death. ${ }^{17}$ Destruction has even been initiated by artists and art dealers. Throughout history, dealers have obtained greater profits by cutting a single painting into several, individually salable paintings. ${ }^{18}$ And, in an interesting twist, some contemporary artists have incorporated the destruction of other art into the creation of their own art. Robert Rauschenberg's self-explanatory 1953 work, Erased de Kooning Drawing, is now in the San Francisco Museum of Modern Art's collection. ${ }^{19}$ Chinese artist Ai Weiwei's 1995 work, Dropping a Han Dynasty Urn, consists of three photographs capturing his dropping a 2000-year-old ceremonial urn, which shatters on the floor. ${ }^{20}$ For a final example, in 2001, English artists Jake and Dinos Chapman purchased a complete set of Francisco Goya's Disasters of War series, a watershed print series in art history, and drew monstrous cartoon faces over Goya's figures. ${ }^{21}$ Whether a standard of care should prohibit these acts by artists is debatable, but it would certainly help in other contexts that jeopardize art.

14. Jeffrey and Carol Horvitz-"We Are Only Stewards of the Art We Acquire," KING BAUDOUIN FOUND. U.S. (Jan. 29, 2019), https://perma.cc/CX2V-5Z44.

15. E.g., SAX, supra note 8, at 68-72.

16. E.g., Ben Widdicombe, Their Warhols Are at the Whitney. Their Ugly Divorce Is on Display, Too., N.Y. TIMES MAGAZINE (Jan. 12, 2019), https://perma.cc/RK2S-VCXT (mentioning tabloid reports of "a scuffle involving a Keith Haring sculpture. ..").

17. See SAX, supra note 8, at 37-42.

18. Id. at 7-8. When a museum exhibition reunites the fragments of a dismantled artwork, it is a cause for celebration, e.g., Anny Shaw and José Da Silva, Two Become One: Mantegna Painting Reunited in National Gallery London Show for First Time in Up To 500 Years, ART NEwSPAPER (Nov. 27, 2018), https://www.theartnewspaper.com/news/two-halves-of-mantegna-painting-reunited-in-national-galleryshow-for-first-time-in-up-to-500-years (two-paneled Andrea Mantegna painting); Holland Cotter, $A$ Hans Memling Show is More Than the Sum of Its Divine Parts, N.Y. TIMES (Sept. 1, 2016), https://perma.cc/S8PH-XJPH (Hans Memling triptych).

19. Robert Rauschenberg, Erased de Kooning Drawing, 1953, S.F. Museum OF MOD. ART, https://perma.cc/Y9Z7-FQG2 (last visited Jan. 7, 2021).

20. Ai Weiwei, Dropping a Han Dynasty Urn, 1995, GugGenHeIM BilbaO, https://perma.cc/X3YN-QVKH (last visited Jan. 7, 2021).

21. Jonathan Jones, Look What We Did, GUARDIAN (Mar. 31, 2003), https://perma.cc/6KNBLKY7. 
To the extent that collectors have a "right to destroy" artwork they own, a narrow exception to this right can be found in the Visual Artists Rights Act of 1990 (VARA). ${ }^{22}$ VARA allows artists to prevent "any intentional distortion, mutilation, or other modification of that work which would be prejudicial to his or her honor or reputation," as well as "any destruction of a work of recognized stature." ${ }^{23}$ But VARA does not impose an affirmative duty of care, since it does not mention neglect as something the artist can enjoin. What is more, VARA only protects a work of art to the extent the artist has a copyright interest in the work; this is consistent with socalled droit moral (moral rights) common in Continental European copyright regimes, on which VARA is based. ${ }^{24}$ The rights VARA confers upon artists survive for either the life of the artist or the duration of the work's copyright, depending on when the work was created. ${ }^{25}$ When the copyright expires, so does the limited physical protection VARA affords to the work.

It is also worth noting that some states enacted art preservation laws prior to VARA, though VARA now preempts those laws to the extent they confer "equivalent" legal or equitable rights. ${ }^{26}$ California's and Massachusetts's laws are nevertheless relevant because, unlike VARA, they are premised on the "public interest in preserving the integrity of cultural and artistic creations." 27 As California State Senator Alan Sieroty wrote in his letter urging the governor to sign the bill, "works of fine art are more than economic commodities and they oftentimes provide our communities with a sense of cohesion and history. The public's interest in preserving important artistic creations should be promoted and our communities should be able to preserve their heritage when it is in jeopardy." 28 This is why both the California and Massachusetts laws extend the right to enjoin the destruction of a work of "fine art" (even, it seems, if that work is privately owned) to not-for-profit arts organizations, as well as extend the term of protection beyond the artist's lifetime or the work's copyright. ${ }^{29}$ Without any reported cases to date in which an organization has sought relief under either state's law, though, it is unclear whether VARA preempts these expanded safeguards.

\section{Freedom of Alienation}

Unlike in some other countries, where the international sale of artworks deemed nationally important is forbidden, ${ }^{30}$ collectors in the United States have total freedom

\footnotetext{
22. 17 U.S.C. $\S 106$ A.

23. 17 U.S.C. $\S 106 \mathrm{~A}(\mathrm{a})(3)(\mathrm{A})-(\mathrm{B})$.

24. See James E. Clevenger, 74 AM. JuR. Proof of FACTS $3 d \S \S 4,10$ (2020).

25. 17 U.S.C. $\$ 106 \mathrm{~A}(\mathrm{~d})$.

26. 17 U.S.C. $\$ 301(f)(1)$.

27. Cal. Civ. Code $\S 989$ (West 2021); MASS. Gen. Laws AnN. ch. 231, § 85S (West 2021).

28. SAX, supra note 8, at 24 (excerpting the September 3, 1982 letter from Sen. Alan Sieroty to Governor Edmund G. Brown Jr.).

29. CAL. CiV. CODE $§ 989 ;$ MASS. GEN. LAWS ANN. ch. 231, $\S 85 \mathrm{~S}$

30. See Art, Cultural Insts. \& Heritage L. Comm., Intl Bar Ass'N, Art Law: RESTRICTIONS ON THE EXPORT OF CULTURAL PROPERTY AND ARTWORK 114 (2020) [hereinafter IBA,
} 
to sell their art. ${ }^{31}$ Collectors can also borrow against their art; the art-finance industry has grown significantly in the past few years. ${ }^{32}$ These rights improve the liquidity of the U.S. art market, but by the same token these rights facilitate the disbanding of collections. When a collector wants to sell artwork-for example, when the heirs of the original collector have little interest in the collection and are faced with a large estate tax - this freedom is a good thing from the perspective of both the collector and the art, since the art will go to someone who presumably values it more.

At other times, though, the disbanding is involuntary. Recently, works from a prominent but ailing collector have quietly made their way to the market as reports have surfaced that he had borrowed over $\$ 90$ million using his art as collateral. ${ }^{33}$ Some companies have also had to sell artwork from their corporate collections due to debt. In February 2020, the Art Newspaper reported that Deutsche Bank, along with cutting 18,000 jobs, had sold or offered works, including works by major artists like Gerhard Richter, Erich Heckel, Max Pechstein, Emil Nolde, and Ernst Wilhelm Nay, from its well-known collection. ${ }^{34}$ Similarly, after declaring bankruptcy in April 2019, the historic Johnson Publishing Company auctioned off its collection of African American art and sold its photo archive, which comprised over four million prints and negatives chronicling seventy years of African American history. ${ }^{35}$ Finally, in the high-profile divorce case of Harry and Linda Macklowe, presiding Justice Laura Drager ordered the couple to sell and divide the proceeds of sixty-four works, valued at an estimated $\$ 700$ million, from their marital collection. ${ }^{36}$ As it

ART LAW]. In 2010, a Spanish collector was sentenced to eighteen months in prison and fined $€ 52.4$ million for smuggling a painting by Picasso out of Spain on his yacht after he was denied a permit to take the work out of the country. Charlie Devereux \& Benjamin Stupples, Jaime Botin Is Sentenced To Prison in Picasso Smuggling Fiasco, BloOMBERG (Jan. 16, 2020), https://perma.cc/A7HW-4FNG.

31. Provided that there is not a cloud on title and that the sale does not violate other laws. In 2012, a controversy arose when the heirs of a collector were subjected to tax liability on a work which they could not legally sell. The piece, Robert Rauschenberg's 1959 Canyon, incorporated a bald eagle which had been killed and turned into taxidermy by one of Teddy Roosevelt's Rough Riders. Although the 1940 Bald and Golden Eagle Protection Act and the 1918 Migratory Bird Treaty Act prohibit trafficking in bald eagles, the Internal Revenue Service valued Canyon at \$65 million and ordered the heirs to pay $\$ 29.2$ million in taxes. After five years of back-and-forth with the IRS, the heirs donated the work to the Museum of Modern Art in New York City, forfeiting any charitable deduction by declaring that Canyon had no value. Eric Gibson, The Illegal Eagle and a Baldly Grasping IRS, WALL ST. J. (Dec. 2, 2012), https://perma.cc/P9VW-PDZU. Such an episode, though, is the exception that proves the general rule about freedom of alienation.

32. See Sarah Douglas, Collectors' Toolkit: Why Is Art Finance a Growing Business?, ARTNEws (June 12, 2020), https://perma.cc/4MAA-XYY9.

33. Kelly Crow, Ailing Art Collector Faces Very Modern Problem: Mountains of Debt, WALL ST. J. (Nov. 18, 2019), https://perma.cc/J5UF-W3SW.

34. Catherine Hickley, Goodbye Gerhard: Deutsche Bank Shrinks Art Collection, ART NEWSPAPER (Feb. 4, 2020), https://perma.cc/97PP-HGYA.

35. Mitch Dudek, Piecemeal Sell-Off of Bankrupt Johnson Publishing Co. Continues with Art Auction, CHI. SUN TIMES (Jan. 2, 2020), https://perma.cc/3JCD-YRL9. The fate of the photo archive was ultimately happy: A group of philanthropic organizations collaborated to purchase the archive, with the intent of donating it to various museums. Peggy McGlone, Foundations Donate Historic Jet/Ebony Archive To African American Museum, WASH. POST (July 25, 2019), https://perma.cc/S4CS-Q3BX.

36. Macklowe v. Macklowe, 2018 NY Slip Op 51834(U) (Sup. Ct. 2018), aff'd, 112 N.Y.S.3d 95 (2019). 
happens, the former Justice Drager oversaw the equitable distribution of an art collection in at least one other divorce proceeding, the case of Kohl v. Kohl ${ }^{37}$ But whereas Justice Drager did not elaborate on her reasoning for the order in Kohl, where the stakes were lower, in the Macklowe case, she explained that although the collection is "extraordinary ... the parties also intended it to be an investment," as shown by the fact that they "did not bequeath any of the art to a not-for-profit entity, nor did they create their own foundation to hold the art, which one might have expected if the intent was to preserve the collection." ${ }^{38}$ Because the collection "served as a device to preserve and increase their personal wealth," Justice Drager concluded that "the sale of these pieces will enable each party to share in most of the value of their lifetime achievement." 39

Thus, the freedom to sell and borrow against art in the private context proves to be double-edged for collectors and collections. On the one hand, these characteristics ensure a robust market that makes possible the creation of collections. On the other hand, because artwork can be sold relatively easily in the United States, collections are inherently unstable and can be converted by the collector, by the collector's creditors, or by a judge. As the next section will explain, those who influence museum practices believe that keeping collections intact on a more permanent basis through special safeguards is better for the public than allowing collections to be subject to forces of change.

\section{B. MUSEUM OWNERSHIP}

\section{Duty of Care}

Unlike collectors, museums are subject to a duty of care, because caring for art is part of their institutional mandate. A 2014 survey by the Institute of Museum and Library Services (IMLS), an independent federal agency, showed that $82 \%$ of museum respondents reported that their mission includes conservation or preservation. ${ }^{40}$ In addition, the American Alliance of Museums (AAM), a not-forprofit association that accredits museums, includes preservation and care in their "Core Standards for Museums," which furnishes the basis for accreditation. ${ }^{41}$ When the museum is negligent in caring for its collection, several consequences can follow. First, the state Attorney General, who oversees charitable organizations, can charge the trustees of the museum with violating their fiduciary duty of care, as in the separate 1970s cases involving the Museum of the American Indian, in New York

\footnotetext{
37. Kohl v. Kohl, 800 N.Y.S.2d 348 (Sup. Ct. 2004), aff'd, 806 N.Y.S.2d 35 (2005).

38. Macklowe, 2018 NY Slip Op 51834(U) at *23.

39. Id. at 24 .

40. InSt. Museum \& LiBr. Servs., Protecting AmericA's Collections: Results From the HERITAGE HEALTH INFORMATION SURVEY (2019), https://perma.cc/DN83-R7ZF.

41. Core Standards for Museums, AM. All. OF Museums, https://perma.cc/5FUG-PFLD (last visited Jan. 7, 2021).
} 
City, and the Maryhill Museum, in Washington State. ${ }^{42}$ Second, if the museum's charitable purpose involves conservation or preservation, the museum can lose its tax-exempt status. Because deductible contributions constitute a key source of museum income, losing charitable status would imperil museum operations. Third, the museum can lose its AAM accreditation, which would indicate the failure of the museum's management to meet professional standards and would thereby deliver a reputational blow. ${ }^{43}$

Caring for their collections can be a major challenge for museums, though. Focusing just on preservation (that is, setting aside the matter of security), the same 2014 IMLS survey showed that $35 \%$ of museum respondents reported experiencing damage to or loss of art in the prior two years, with almost half of those museums citing improper storage as the cause. ${ }^{44}$ And, while the IMLS survey emphasized that small museums face the greatest challenges with respect to improving storage, actions taken by large museums suggest that they too find it difficult to fulfill the obligations of care. During his tenure from 1997 to 2015 as the director of the Brooklyn Museum, Arnold Lehman responded to a problem of inadequate storage by consolidating the museum's collection and offering works to other institutions. ${ }^{45}$ In the words of another museum director, who cancelled a plan to double his museum's storage space in favor of relinquishing works, "[t]here is this inevitable march where you have to build more storage, more storage, more storage. I don't think it's sustainable." 46

\section{Restraints on Deaccessioning}

The "inevitable march" towards larger collections that require more storage and pose an increasing financial threat to museums happens because museums are limited in their ability to deaccession works. Following a controversy over an impropriety by the Metropolitan Museum of Art in the 1960s, in which the museum secretly sold works that had been bequeathed to it on the condition that they never be sold, museums established internal deaccessioning policies. ${ }^{47}$ A deaccessioning policy

42. Lefkowitz v. Museum of the Am. Indian Heye Found., No. 41416/75 (N.Y. Super. Ct., N.Y. County, June 27, 1975) (alleging waste and surreptitious behavior by the trustees in the disposition of artifacts from the collection); State of Wash. ex rel. Gordon v. Leppaluoto, Nos. 11777 \& 11781 (Wash. Super. Ct., Klickitat County, 1977) (alleging neglect that resulted in damage and loss to works from the collection). Both cases are discussed in Stephen E. Weil, Breaches of Trust: Remedies and Standards in the American Private Art Museum, 2 InT'L J. Museum MgMt. \& CURATORSHIP 53, 58 (1983).

43. See Sue Chen, Art Deaccessions and the Limits of Fiduciary Duty, 14 ART, ANTIQUITY \& L. 103, 134-35 (2009); Jori Finkel, Whose Rules are These, Anyway?, N.Y. TIMES (Dec. 24, 2008), https://perma.cc/GGZ4-P8BG.

44. INST. MUSEUM \& LIBR. SERVS., supra note 40. As for security, see Alice Farren-Bradley, What Makes a Museum Secure?, APOLlo (Mar. 1, 2016), https://perma.cc/5UXG-MV2A.

45. Robin Pogrebin, Clean House to Survive? Museums Confront Their Crowded Basements, N.Y. TiMES (Mar. 12, 2019), https://perma.cc/Q8BP-R9LE.

46. $I d$.

47. See John L. Hess, De Groot Inquiry Brings To Limelight Benefactor of Metropolitan Museum, N.Y. Times (Feb. 18, 1973), https://perma.cc/28C6-4GBD (contemporary reporting of the Met 
provides guidance and transparency for when and how the museum will sell works in their collections. For example, the National Gallery of Art in Washington, D.C., does not deaccession at all, while the Museum of Modern Art in New York City has a policy of deaccessioning more regularly in order to cull its collection. ${ }^{48}$ On the one hand, a deaccessioning policy provides reassurance to donors, and it helps the museum avoid the chilling effect on future donations that selling works contrary to donors' wishes would have. On the other hand, such a policy can create inflexibility and lock the museum into ownership of works that later become burdensome to steward.

In addition to museums' internal policies, the AAM and the Association of Art Museum Directors (AAMD) promulgate their own ethical guidelines for deaccessioning. These guidelines, though technically non-binding, further restrict the ability of museums to deaccession. The AAM Code of Ethics for Museums dictates that sale proceeds from deaccessioning can be used only to make new acquisitions of works or to provide for the "direct care" of the collection. 49 "In no event," the AAM states, "should the potential monetary value of an object be considered as part of the criteria for determining whether or not to deaccession it."50 The AAMD policy likewise requires that "[p]roceeds from a deaccessioned work are used only to acquire other works of art- the proceeds are never used as operating funds, to build a general endowment, or for any other expenses." 51 The rationale for these guidelines is the notion that museums hold their art in "public trust," which the AAM defines as "the principle that certain natural and cultural resources are preserved for public benefit." 52 According to the AAM, the public trust doctrine means that "the public owns the collections, and they should be kept available so the public can study them, enjoy them, and learn from them"; it also precludes treating the works as financial assets. ${ }^{53}$ The AAM Code of Ethics considers that museums in the United States are organized as such "trusts." 54

controversy); David R. Gabor, Deaccessioning Fine Arts Works: A Proposal for Heightened Scrutiny, 36 UCLA L. REV. 1005, 1013 n.42 (1989) (proposal for new deaccessioning policies); Gerstenblith, supra note 6, at 421 n.58 (analysis of deaccessions and fiduciary obligations); Jason R. Goldstein, Deaccession: Not Such a Dirty Word, 15 CARDOZO ARTS \& ENT. L.J. 213, 221 (1997) (supporting deaccessioning in general); Chen, supra note 43, at 103-04 (analysis of deaccessions and fiduciary obligations); see generally Selby Whittingham, Breach of Trust over Gifts of Collections, 4 INT'L J. CULTURAL PROP. 255 (1995) (analysis of deaccessions in a contractual framework).

48. See Gifts of Art, NAT'L GALLERY OF ART, https://perma.cc/8MZ6-ZZXM (last visited Jan. 7, 2021); Museum of Modern ARt, Collections Management Policy 7-8 (Apr. 20, 2020), https://perma.cc/FKW8-KTY9.

49. Am. All. of Museums, Direct Care of Collections: ethics, Guidelines and RECOMMENDATIONS 1 (March 2019), https://perma.cc/P9DM-FE3W.

50. Id. at 6 .

51. Ass'N of Art Museum Dirs., Art Museums and the Practice of Deaccessioning (2007), https://perma.cc/R52C-TPSB.

52. Questions and Answers About Selling Objects from the Collection, AM. ALL. OF MuSEUMS, https://perma.cc/Q2JU-XXYF (last visited Jan. 7, 2021).

53. Id.

54. Am. All. of Museums, Code of Ethics for Museums, https://perma.cc/M5WM-CMA8 (last visited Feb. 4, 2021). 
Despite their status as guidelines, the AAM's and AAMD's ethical framework is highly influential in guiding deaccessioning decisions. Both organizations have powerful sanctioning tools: The AAM can revoke its accreditation of a museum in violation of its Code of Ethics, and the AAMD can ask its other members to suspend lending artwork and sharing exhibitions with that museum. ${ }^{55}$ While losing accreditation is a major reputational embarrassment, the de facto denial of access to loans and exhibitions can be a "death knell" for a museum that relies on exchange to exhibit new art and continually attract visitors. ${ }^{56}$ Even without censure, mere condemnation by the AAM and AAMD can create a backlash of opprobrium that forces the museum to change course. Sue Chen has highlighted instances in which AAMD condemnation compelled museums to reconsider deaccessions that would have violated the ethical guidelines. ${ }^{57}$

\section{RECONSIDERING PRIVATE OWNERSHIP REFORM}

Much of the scholarship concerned with reforming private ownership of art has premised the desirability of such reform on the "public interest in art." As Part I explained, the public interest provides the rationale for the museum's obligations as well as for the California and Massachusetts preservation laws (but not VARA, whose prohibition against destruction is designed primarily with the artist's rights in mind). What is less certain, though, is that resolving these two discrepancies between private and museum ownership would fully, or even sufficiently, vindicate the public interest. Assuming that there is a public interest in art, what is its scope?

In the United States, John Henry Merryman has been foundational in defining the public interest in art and its implications for arts policy. Few have considered the public interest in privately owned art specifically, though. ${ }^{58}$ In this section, I introduce Professor Merryman's basic framework and then turn to Joseph Sax, who accepted Merryman's ideas in arguing that the public interest extends to privately held art but is insufficiently supported at present. I then examine more recent

55. See generally Chen, supra note 43 .

56. Finkel, supra note 43 ("She called the withdrawal of loans 'a death knell' for the museum, adding 'What the A.A.M.D. have done is basically shoot us while we're wounded."'). The financially struggling National Academy Museum in New York City decided to sell two paintings from its collection to shore up its finances. After AAMD condemnation, the museum closed in 2016. See Randy Kennedy, National Academy Plans To Sell Two Fifth Avenue Buildings, N.Y. Times (Mar. 17, 2016), https://perma.cc/GVT2-NBCB.

57. Chen, supra note 43, at 115 (noting that AAMD condemnation compelled the Fogg Art Museum, part of Harvard University, to cancel a deaccession intended to raise money for the construction of a new wing, and the Phillips Collection, in Washington, D.C., to apply the proceeds of a deaccessioned Braque painting to its acquisitions fund rather than to its endowment as was initially intended).

58. Legal interest in private collecting beyond matters of title and restitution appears to be growing, especially outside of the United States. Internationally, the work of Elina Moustaira, see ART Collections, Private and Public: A Comparative Legal Study (2015), and Jorge Sanchez Cordero, see The Private Art Collections, 20 UNIFORM L. REV. 617 (2015), are helpful starting points for further research, as are the scholars referenced in INT'L INST. FOR THE UNIFICATION OF PRIVATE LAW (UNIDROIT), Private Collections, Historical and Legal Perspectives (Mar. 16-17, 2017), https://perma.cc/N2GE-SJQG. 
exponents of Professor Sax's argument in order to show how it has been received and developed. I single out this paradigm - both in Sax's original form and as subsequently advanced - for critique because, in this nascent area of scholarship, Sax's study is particularly well-researched and detailed; it also stands antithetical to my own view. As Sax remains a prominent guide to thinking about the public interest in privately held art, I hope that the ensuing Part will provide a counterpoint to his assessment. My reassessment informs the proposal in Part III for a different solution to the shared goal of promoting the public interest in privately held art.

\section{A. "The ESSENTIAL ISSUe Is ACCESS"}

In one of his many influential essays on this subject, John Henry Merryman posited both the sources and the implications of the public interest in "cultural property," which for the purpose of this argument can be used interchangeably with art. $^{60}$ Professor Merryman identified three values inherent to cultural property that contribute to the public interest: an expressive value, by which art conveys human concepts like collective memory or the mores of a particular community; a political and religious value, by which art is "put to a variety of political uses in a variety of political contexts"; and a utilitarian value, by which art informs our understanding of humans and human history, enriches our lives by providing aesthetic pleasure, and serves as a form of wealth. ${ }^{61}$ From these origins, Merryman derived the aspirations for the public interest. "The elements of a cultural property policy," Merryman argued, are preservation, truth (meaning investment in proper study and interpretation), and access. ${ }^{62}$

Taking Merryman as a starting point, as many have, ${ }^{63}$ it appears that supporting the public interest in art requires something more than a heightened standard of care and restraints on alienation in the private context. Indeed, neither one of those measures would do much to further the public interest under Merryman's formulation. Imposing a heightened standard of care might better protect art in the marginal case, but as Part I argued, financial incentives, the ethics of stewardship, and common sense are good substitute guarantors of preservation. As for restricting alienation, that would do nothing for preservation, truth, or access; if anything, the

59. SAX, supra note 8 , at 66 .

60. John Henry Merryman, The Public Interest in Cultural Property, 77 CALIF. L. REV. 339, 341 (1989). Merryman defines "cultural property" as "objects that embody the culture-principally archaeological, ethnographical and historical objects, works of art, and architecture; but the category can be expanded to include almost anything made or changed by man."

61. Id. at $345-55$.

62. Id. at 355-63.

63. See generally COMPARATIVE AND PRIVATE INTERNATIONAL LAW: ESSAYS IN HONOR OF JOHN HENRY MERRYMAN ON HIS 70TH BiRTHDAY (D.S. Clark, ed.) (1990). According to HeinOnline, Merryman's article, Two Ways of Thinking About Cultural Property, 80 AM. J. INT'L L. 831 (1986), has been cited 219 times, and The Public Interest in Cultural Property, 77 CAL. L. REV. 339 (1989) has been cited 146 times. One of the leading scholars who responds to Merryman is Patty Gerstenblith, e.g., Identity and Cultural Property: The Protection of Cultural Property in the United States, 75 B.U. L. REV. 559 (1995); The Public Interest in the Restitution of Cultural Objects, 16 CONN. J. INT'L L. 197 (2001). 
freedom to sell one's art produces the financial incentive to preserve it. For this reason, scholarly proposals to vindicate the public interest in art have focused on the issue of access. Merryman framed access as the justification for a freer exchange of cultural property among nations so that more people could come into contact with the work. ${ }^{64}$ Access presupposes preservation - without the artwork, there can be no access to it - and it also is a precondition for truth, as access is essential to the study and interpretation of the work.

Whereas Merryman assumed for his argument that the artwork in question would remain publicly owned, ${ }^{65}$ Joseph Sax looked at the issue of access in the context of private ownership. As to preservation, Professor Sax concluded that the majority of collectors care about being good stewards of their collection. ${ }^{66}$ As to access, though, he considered the lack of public access to privately held treasures the "essential issue" and a "more pervasive problem than destruction or mutilation." ${ }^{67}$ As a natural consequence of the right to exclude, inaccessibility inheres in ownership even more fundamentally than does destruction. ${ }^{68}$ But in contrast to the lack of a standard of care, for which various factors compensate to make destruction a minor issue, Sax regarded the factors that motivate "voluntary arrangements for access" as ultimately insufficient to vindicate the public interest. ${ }^{69}$ Such factors include public incentives like tax benefits for charitable donations, social prestige, and the cajoling of museum directors. ${ }^{70}$ For certain works of art, Sax argued that their importance necessitates public access and a limit on the otherwise unqualified right of collectors to exclude.

Sax's proposed solution was to create a duty for owners of "major holdings in their collections" to act as "successful, satisfied, responsible major collectors" with respect to granting public access. ${ }^{71}$ Such a duty might compel a newfound generosity among the collectors Sax points to in identifying the problem. For example, a certain Nicholas van Hoogstraten was quoted as saying, "[t]here won't be any riff-raff coming in, standing on the Persian carpets. ... This is a private museum for me," while Calouste Gulbenkian liked to say of his home and collection, "Would I admit a stranger to my harem?"72 As Sax observes, he was not the first to suggest a duty to provide access. ${ }^{73}$ But to implement this duty, Sax outlined a "system of obligatory,

64. See John Henry Merryman, Two Ways of Thinking About Cultural Property, 80 AM. J. INT’L L. 831, 852-53 (1986). A contemporary discussion exists regarding how Merryman's argument relates to the politics of acquisition and display, but these issues are beyond the scope of this Note.

65. Id. at 852 .

66. SAX, supra note 8, at 68-73 ("[C]ollectors usually treasure their possessions and protect them from harm"; tracing the conception of the art collector as steward from the middle ages to the modern day and concluding that the "stewardship tradition is obviously powerful and deeply rooted").

67. Id. at 8,66 .

68. See id. at $1 \mathrm{n} .2$ ("Whether law has ever recognized a right to destroy ... is uncertain.... Writers on the civil law take a more measured view: '[T]he abuse of things that belongs to us may be without punishment, it is never permitted."' (quoting C. B. M. Toullier)).

69. Id. at 66 .

70. Id.

71. Id.

72. Id. at $64-65$.

73. Id. at 66 . 
expense-compensated loans to public institutions."74 In his scheme, a "committee of experts operating under the auspices of a national museum" would create a list of important artists and/or artworks subject to compulsory exhibition for a specified duration at one or more designated places in the United States. ${ }^{75}$ Forcing the national museum to bear the costs of transport and display of the work would minimize the financial impact on the collector and ensure that the museum exercised restraint in determining what works are subject to the regime. ${ }^{76}$

The notion that the public interest in art encompasses preservation, truth, and access (from Merryman), the emphasis on inaccessibility in the private context (from Sax), and Sax's proposal for reform have been adopted and refined in subsequent scholarship. Recently, Hope Babcock acknowledged the influence of Sax's scholarship in her essay exploring the public trust and public dedication doctrines as alternative means of facilitating public access. ${ }^{77}$ Professor Babcock asserts that some art "is of such value to a country's self-identity that one might properly call it public art, even though the art is privately owned"; "[p]rivate hoarding" of this art, she claims, "deprives ordinary people of access to works of national importance and thus undermines republican values like education, community, and citizenship." 78 Babcock argues that museums have been "priced out of the art market" by collectors and that the resulting stasis of museum collections, because they cannot acquire new works, diminishes museums' educational value. ${ }^{79}$ Finding an obligation among collectors towards the public "in the republican values of citizenship and education," Babcock determines that, where other incentives fail, applying the public trust doctrine to "privately held important works" would be the best way to enforce this obligation. ${ }^{80}$ Similarly, in a student Note, Nicole Wilkes proposes a "National Art Register" to identify "culturally significant works of art." ${ }^{\text {" } 11}$ Wilkes recommends best practices for the care and stewardship of this art, and she calls for legislation prohibiting acts to the detriment of the work as well as obligating the collector to provide public access. ${ }^{82}$ Wilkes conceives of both the register and the legislation as a means of "standardiz[ing] how private property owners use and care for certain types of objects (i.e., carrying out their role as stewards), while still leaving the property in private hands." ${ }^{\prime 3}$ Together, Babcock and Wilkes illustrate how the framework developed by Merryman and Sax has defined a paradigm for thinking about the public interest in privately owned art.

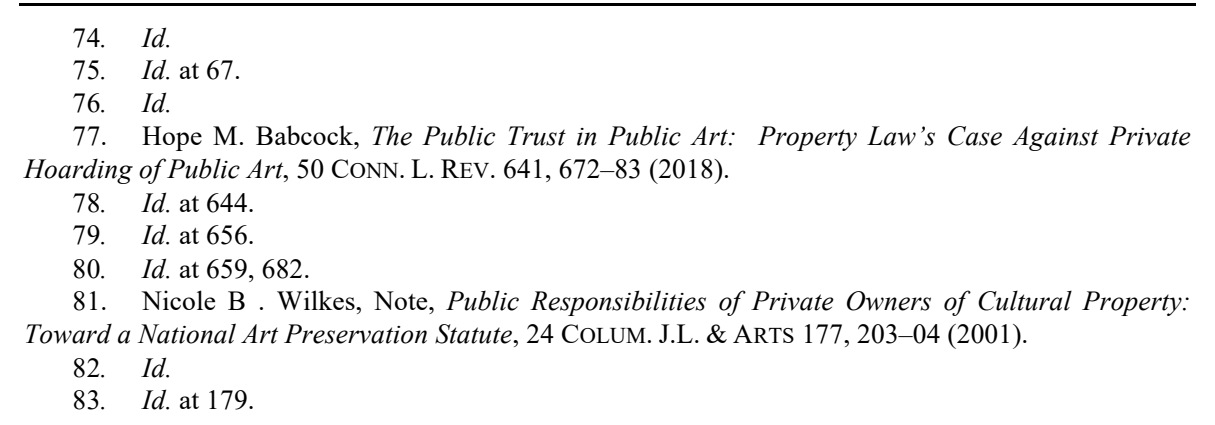




\section{B. Determining Cultural Significance}

The essential caveat to the proposals within this paradigm is that the obligation to provide access would apply only to works of art deemed important enough that the public interest in access outweighs the private interest in exclusion. Confining the scope of an involuntary loan or easement-like regime in this way is meant to achieve a balance between public and private interests. It also responds, as Sax suggested, to the criticism that curtailing ownership rights would discourage collecting, although it should be recognized that downplaying the potential disincentive to collect assumes that private collecting is, on some level, socially desirable.$^{84}$ In any event, one can therefore characterize this paradigm as focused on individual artworks. Accepting the premise that access would vindicate the public interest, the question then becomes, in what works does the public have a prevailing interest? This calls for a standard for determining what one might term "cultural significance"- the quality that necessitates access.

Although Sax did not articulate a standard, reasoning that having the museum bear all costs would limit the list of important works to obvious cases, Wilkes and Babcock do provide their own standards. For her proposed National Art Register, Wilkes adopts the National Endowment for the Arts' framework for determining which properties qualify for the National Register of Historic Places. ${ }^{85}$ The NEA provides that a property may be registered if it meets one of the following criteria: (a) it is "associated with events that have made a significant contribution to the broad patterns of our history"; (b) it is "associated with the lives of persons significant in our past"; (c) it "embod[ies] the distinctive characteristics of a type, period, or method of construction, or [it] represent[s] the work of a master, or [it] possess[es] high artistic values, or [it] represent[s] a significant and distinguishable entity whose components may lack individual distinction"; or (d) it has "yielded, or may be likely to yield, information important in prehistory or history." ${ }^{" 86}$ In addition to this inquiry, Wilkes adds the threshold requirements that the artwork in consideration be at least fifty years old and have a fair market value in the top $20 \%$ of works in its particular medium. ${ }^{87}$ With its combination of subjective and objective criteria, Wilkes's standard is better than Babcock's, which is entirely subjective and rather nebulous. Pulling together various descriptions from Sax, Merryman, and other authors, Babcock defines "public" (culturally significant) art as that which "carries the "essence' of the nation" and "provides the "basis of cultural memory," "and so forth. ${ }^{88}$

A related consideration is which institution should make the determination of cultural significance. For one thing, there is a conflict of interest where the body making the determination will benefit from the opportunity to make the work available to the public. Thus, while Sax proposed placing the decision in a committee

\footnotetext{
84. See SAX, supra note 8 , at $65-67$.

85. Wilkes, supra note 81, at 205-06.

86. 36 C.F.R. $§ 60.4$ (2020).

87. Wilkes, supra note 81, at 205-06.

88. Babcock, supra note 77 , at 646-47.
} 
within a national museum, one could alternatively empower a committee of museum professionals, such as directors or curators, whose own institutions would be excluded from receiving the work in question. How broadly or narrowly to define the relevant decision-maker is another concern: In contrast to Sax, who conceived of cultural significance as a national question, Wilkes and Babcock both consider that smaller communities may have a valid interest in an artwork which is significant only to the local public. For this reason, Wilkes proposes either a committee consisting of a "geographic and substantive cross-section of art historians, artists, expert dealers, curators, museum directors, and arts administrators," or local committees including public representatives who have knowledge of what is culturally significant to the relevant community. ${ }^{89}$ While Wilkes's and Babcock's observation about local significance is true, there must be a limit on the smallest community that could legitimately claim an interest in an artwork, or else there would always be some faction to compel access to any work. Nevertheless, Wilkes's idea to diversify the actors involved in making the determination is a good one, because even an independent committee of museum professionals would have a natural bias in favor of the public over the collector. Another collector-friendly measure would be to limit the total number of artworks that could be eligible for a forced loan at any given time. Regardless, both the standards for determining cultural significance and the composition of the body that makes that determination should reflect careful consideration as to how to balance the interests of the collector and the public.

\section{Critiquing This Proposal}

In the end, though, this paradigm of providing access to significant artworks on an individual basis would be exceedingly difficult to implement and would also fail to affirm the public interest. Practically, identifying privately owned, significant works would be nearly impossible, especially if a proposal of this kind encountered resistance from collectors. But just as importantly, collectors, museums, and the public can have a collaborative relationship, and this relationship counsels in favor of a different approach to reconciling private collecting and museum ownership for the public benefit.

\section{Practical Challenges}

It might not be clear initially why a collector would oppose a finding that his or her work is significant under such a scheme. On one hand, having an official label of cultural significance attached to an artwork might reduce the value of the work by making it subject to a compulsory loan and therefore less desirable to own. On the other hand, it could enhance the owner's reputation as a collector, and it could be a source of value for the work. Inclusion of an artwork in a museum exhibition, to use an analogy, adds pedigree and thus value to a work. The consequences of the

89. Wilkes, supra note 81 , at 206. 
determination would depend on whether the market already appreciated the qualities of the artwork that made it significant (in which case the determination would not add value $)^{90}$ and whether the work's being made subject to the loan scheme would in fact reduce demand, as it may well be that the echelon of collectors able to own certain trophy works will compete for them under any circumstances. ${ }^{91}$ Thus, although "cultural significance" would undoubtedly provide a reputational benefit, its monetary effect is less certain. It seems fair to say that collectors would have different preferences in balancing prestige, valuation, and full ownership privileges.

Additionally, if an obligation to provide access were implemented, unenthusiastic collectors would be able to avoid detection anyway by taking advantage of the art market's opacity. Privacy is a strong norm in the art market for reasons both valid and illicit, ${ }^{92}$ and current law protects privacy: Unlike a car or a home, owners need not register their art in the United States. ${ }^{93}$ Of the significant works that are privately held, some are publicly known because they have appeared on the market, and still more are secretly known to museum professionals and dealers, but the suggestion that one could simply compile anything close to a comprehensive list is quixotic. Moreover, cooperation among museum professionals cannot be automatically

90. Indeed, the esoteric nature of the art market affords legal judgments little weight with respect to valuation in other contexts. For example, a legal determination that a Richard Prince work constitutes copyright infringement will not destroy its value, nor will the legal attribution of a disputed work to Alexander Calder convince a skeptical market to value the work as genuine. Although Cariou v. Prince, 714 F.3d 694, 698-99 (2d Cir. 2013) held that certain artwork by Richard Prince is infringement, months after that decision, Prince's gallery held a new exhibition of his work which used a similar style of appropriation to the one at issue in Cariou, Gagosian, RiCHARD PRINCE: New PORTRAITS (Sept. 19Oct. 24, 2014); allegedly those works were sold for $\$ 100,000$, Hannah Jane Parkinson, Instagram, an Artist and the \$100,000 Selfies-Appropriation in the Digital Age, THE GuARDIAN (July 18, 2015), https://perma.cc/V449-TA5A. In Thome v. Alexander \& Louisa Calder Found., 890 N.Y.S.2d 16, 23-27 (2009), the court acknowledged, "Whether the art world accepts a catalogue raisonné as a definitive listing of an artist's work is a function of the marketplace, rather than of any legal directive or requirement ... For [a judicial pronouncement of authenticity] to have any validity in the marketplace or the art world, it would have to be supported by the level of justification sufficient to support a pronouncement by a recognized art expert with credentials in the relevant specialty ... in [actions to determine authenticity], the relief awarded by the court binds only the parties to the transaction, and does not attempt to affect the art market generally. Although it is possible for a court's pronouncement regarding a work's authenticity to have an impact on the work's market value, any such impact would be an incidental effect of the decision rather than its central purpose." But, as suggested in the text, a label of cultural significance appears more akin to something like inclusion of the work in an exhibition than to a finding of infringement or attribution.

91. Similarly, because this scheme wouldn't limit the overall market for the work, the forced loan scheme can be distinguished in terms of its market effect from legal regimes that prohibit the export of certain works, usually identified as objects of "cultural patrimony," which do limit the market to the relevant nation. See ART LAW supra note 30.

92. Valid reasons might include a desire to preserve the art market's rarefied status by not conducting commerce so overtly, or embarrassment if, say, the collector were selling a family heirloom. Illicit reasons might include trafficking in stolen art or money laundering. See generally Art Law and the Art Market: Disclosure or Discretion?, SOTHEBY'S INST. OF ART, https://perma.cc/5TTE-TAXL (last visited Jan. 17, 2021); Timothy L. O'Brien, Corporate Art Lovers Who Hate That Big Tax Bill, N.Y. Times (May 9, 2004), https://perma.cc/BYN7-XGN6; Allyson Shea, Note, Shooting Fish in a Bliss Bucket: Targeting Money Launderers in the Art Market, 41 COLUM. J.L. \& ARTS 665, 666 (2018).

93. THOMAS W. MERRILl \& HENRY E. SMITH, PROPERTY 166 (2010). 
expected: Why would one museum director, who perhaps hopes to secure the donation of a work for his or her own institution, divulge the existence of the work and be forced to share it with other museums? And dealers would never disclose such information, for their business is pairing buyers and sellers within their network. In this light, it is telling that every one of Babcock's examples of "public" art is already in a museum. ${ }^{94}$ At the same time, a categorical approach to identifying culturally significant works (say, all paintings by Jackson Pollock, or all official portraits of U.S. Presidents) would destroy the case-by-case limitation that is essential to the proposals. ${ }^{95}$

The practical limitations of this approach are clear when considering the reality of how owners behave, which is supported by law. The best workaround for identifying new works of significance would be to monitor the market, but this approach also faces challenges. It might, for example, simply channel more business to private dealers. As for the open market at auction, buyers and sellers can conceal their identities by transacting through an alias such as an agent or a separate company. This is true even vis-à-vis the auction house itself. While the United Kingdom recently passed regulations requiring that auction houses (and dealers) perform the same "know your client" (KYC) checks and due diligence as banks, accountants, and lawyers when overseeing art transactions of a certain size, no similar rule currently exists in the United States. ${ }^{96}$ As a result, under the current law, both the seller and the buyer can transfer artwork with anonymity even from the intermediary, whether the transaction occurs publicly, at auction, or privately, through a dealer. This practically forecloses the possibility of tracking significant works of art.

\section{The Public Value of Private Collections}

But even assuming that a proposal for public access like Sax's could be implemented, would it vindicate the public interest? Is "private hoarding" as serious a problem as Sax and Babcock make it out to be? The answer is probably not, for two reasons. First, this approach has an unduly pessimistic view of collectors and establishes a false opposition between the interests of museums and private collections. In fact, there is a great deal of synergy between collectors and museums that takes many forms. Further, some collectors espouse a model of collecting that

94. Babcock, supra note 77, at 646-47. Babcock lists Emanuel Leutze's "Washington Crossing the Delaware," Gilbert Stuart's "George Washington," Andrew Wyeth's "Christina's World," Edward Hopper's "Night Hawks," and Winslow Homer's "The Veteran in a New Field." These paintings are in the collections of the Met, the National Portrait Gallery (or else the National Gallery of Art or the Met; Stuart painted multiple portraits of Washington), MoMA, The Art Institute of Chicago, and the Met.

95. Many "cultural patrimony" export laws take this approach. See IBA, ART LAW supra note 30, at 113 .

96. Kenneth Mullen \& Diana Wierbicki, Ready or Not, New UK Anti-Money Laundering (AML) Regulations Hit UK Art Sector from 10 January 2020, WitHERS WORLDWIDE (Jan. 3, 2020), https://perma.cc/6ZHT-DR5N; Peter D. Hardy, Art and Money Laundering, NAT'L L. REV. (Mar. 20, 2019), https://perma.cc/YUV4-4NA7. 
can serve the public interest, and under this model, collectors have certain advantages that museums lack as far as conferring a public benefit. Seen in this light, the desire to provide access to individual works of art is a flawed form of relief, for it fails to capture how museums create meaning through their collections. Collections provide context; the connections between works within this context produces insight. ${ }^{97}$ Hence the role of the curator, who in addition to being a caretaker of the works under his or her purview, is an expert in creating contexts through presentation that facilitates this process. If the purpose of access is to promote meaning or "truth," then to truly affirm the public interest, an approach to privately held art must focus on collections in their entirety rather than on individual works. A myopic approach that emphasizes access to a single work will simply not achieve Sax's and his successors' goal.

Collectors do act generously by lending and donating artwork to museums, as Sax and Babcock acknowledge when they propose using the mandatory loan only as a last resort, after other incentives have failed to produce the desired outcome. These incentives, including social prestige, tax, and valuation benefits, and even sincere generosity, are more effective than Sax and Babcock suggest. ${ }^{98}$ One has to be willing to take the long view in this regard, but over time, great works almost inevitably flow to the museum. It could be said, with little exaggeration, that museum collections are aggregations of formerly private collections. The Metropolitan Museum of Art houses several of these collections, most notably, Robert Lehman's extraordinary bequest of 2,600 works, for which an entire wing of the museum was built in 1975. ${ }^{99}$ In the last decade, brothers Leonard and Ronald Lauder have pledged major gifts to the Met: from Leonard, "one of the foremost collections of Cubism in the world"; from Ronald, "the most significant grouping of European arms and armor given to the Museum since 1942." 100 In March 2020, the Cleveland Museum of Art announced that it had received its largest gift in more than sixty years, a collection of over one hundred works, including European and American paintings, drawings, and prints, along with Chinese and Japanese ceramics. ${ }^{101}$ Collectors might be wary of turning their own home into a museum, but the characterization of the collector as disdainful of the public ${ }^{102}$ does not seem to fit serious collectors, many of whom collect with the goal of making a museum bequest in mind.

97. See Andrew J. Pekarik, From Knowing To Not Knowing: Moving Beyond "Outcomes," 53 CURATOR 105, 112 (2010).

98. See generally Allison Anna Tait, The Secret Economy of Charitable Giving, 95 B.U. L. REv. 1663 (2015).

99. The Robert Lehman Collection, METRO. MUSEUM OF ART, https://perma.cc/YEV6-2BY6 (last visited Jan. 17, 2021).

100. Metropolitan Museum Announces Gift of Major Cubist Collection Comprising 78 Works by Picasso, Braque, Gris, and Léger from Leonard A. Lauder and Creation of New Research Center for Modern Art, METRO. MuSEum OF ART (Apr. 9, 2013), https://perma.cc/D9XS-WR6Q; The Metropolitan Museum of Art To Receive Major Gift of European Arms and Armor from Ronald S. Lauder, METRO. MUSEUM OF ART (Dec. 9, 2020), https://perma.cc/V9PD-3CWB.

101. The Cleveland Museum of Art Announces Largest Gift in More than Sixty Years, CLEVELAND MUSEUM OF ART (Mar. 11, 2020), https://perma.cc/LKN9-HUAC.

102. See supra note 72 . 
While many of the largest American museums comprise several bequeathed collections, sometimes a single private collection constitutes the basis of the museum. Individual private collections turned public institutions represent some of the most important American museums. ${ }^{103}$ More recently, so-called "private museums," individually controlled museums which are tax-exempt because they provide some public benefit, have proliferated. ${ }^{104}$ Newer private museums include the Broad Museum, in Los Angeles, the Brant Foundation, in Connecticut, Glenstone, in Maryland, and initially, the Crystal Bridges Museum of American Art, in Arkansas (which has since converted to a public museum). While valid criticisms have been raised regarding the potential abuse of the private museum structure, ${ }^{105}$ this ought to be an argument for reforming the tax code rather than for dismissing private collecting as unable to further public goals.

I would argue that the prominent role of the collector in the U.S. enriches the cultural landscape because private collections are better able than museum collections to express a unique perspective on art. Public museums have boards of trustees and acquisition committees that set collecting priorities and deliberate potential acquisitions. In contrast, collectors are more amateur in terms of expertise, but they also have an independence to pursue their own desires. This freedom has produced private collections of singular vision and ingenuity. It is what allowed Dr. Alfred Barnes, the collector behind the Barnes Foundation, to amass one of the world's greatest collections of Impressionist, Post-impressionist, and early modernist paintings before the American public and art establishment had come to appreciate the likes of Renoir, Cézanne, Matisse, and Picasso. ${ }^{106}$ Or, one could look at Harvard University's Dumbarton Oaks Institute, in Washington, D.C., which receives tens of thousands of visitors yearly to its historic garden and museum, while also serving as a research center for Byzantine, Pre-Columbian, and Landscape Studies. ${ }^{107}$ The peculiar combination of fields reflects the interests of Robert and Mildred Bliss, who collected Byzantine and Pre-Columbian art as well as maintained a renowned garden before donating their estate to Harvard in $1940 .{ }^{108}$ For a contemporary case, in 2019, J. Tomilson and Janine Hill established the Hill Art Foundation in New York City to make their collection, which juxtaposes Renaissance bronze sculpture and contemporary painting, freely available to the public. ${ }^{109}$ These examples show how

103. These include, just to name a few examples, the Barnes Foundation, in Philadelphia, the J. Paul Getty Museum, in Los Angeles, the Isabella Stewart Gardner Museum, in Boston, the Phillips Collection, in Washington, DC, the Freer and Sackler Galleries, also in Washington, the Kimbell Art Museum, in Fort Worth, and several in New York City, such as the Frick Collection, the Guggenheim Museum, the Neue Galerie, and the Whitney Museum of American Art.

104. See Kirk, supra note 2, at 869-70.

105. See id. and infra Part III.A.

106. Roberta Smith, A Museum, Reborn, Remains True To Its Old Self, Only Better, N.Y. TIMES (May 17, 2012), https://perma.cc/N3BK-RMAA.

107. Home of the Humanities, DUMBARTON OAKS, https://perma.cc/XV5R-BXXT (last visited Jan. 17, 2021).

108. Id.

109. About the Foundation, HILl ART FouND., https://perma.cc/W5NH-8NKY (last visited Jan. 17, 2021). 
great private collections attest to passion, conviction, and inspiration in a way that encyclopedic museum collections cannot. When they are open to the public, private collections make special contributions that complement rather than displace the museum.

The contribution of Dr. Barnes, the Blisses, or the Hills point to the importance of thinking about collections holistically rather than in terms of individual works. Speaking about collectors, the director of the Grolier Club, the nation's oldest bibliographic society, once testified that a "collector" is somebody "taking a new approach to putting together a collection . . the goal being to discover something about these books that wasn't known before or that allows scholars and collectors to look at these books in a new way." 110 This describes Dr. Barnes, who, after opening a school for art history in 1925, displayed his modern paintings alongside African masks, native American jewelry, Greek antiquities, and decorative metalwork, reflecting his own narrative of art. ${ }^{111}$ A true "collection" invites one to find connections among artworks; discovering these visual and intellectual connections is what makes the experience of a collection different from reading about a culturally significant work in a textbook. ${ }^{112}$ This is the point that proposals like Sax's miss when, in arriving at a limiting principle that balances public and private interests, they locate the public interest in specific works of art. True, a museum could contextualize a significant work within its collection during the duration of the loan. But the problem is that, once one gets past the practical challenges of identifying significant works of art, fixating on them overlooks the greater source of public value that is private collections as a whole. Moreover, when one removes a significant work to the museum, any contextual benefit that the collection might offer is lost.

Thus, along with the infeasibility of implementing a duty for collectors to provide public access, a duty of access would be misguided, if not undesirable. The relative advantages of private collecting over the museum, namely, flexibility and innovation, have helped produce collections that are celebrated by the public today. Recognizing this calls for vindicating the public interest by means of providing access to collections rather than specific works.

\section{A NEW PROPOSAL}

\section{A. A COllection-Minded Approach}

Shifting the attention from significant artworks to significant collections reveals the need for a different paradigm for supporting the public interest in privately held art. Assuming the goal is to promote the stewardship and study of the collection as a whole, then the model for behavior should not be "successful, satisfied, responsible

110. In re Gourary, 932 N.Y.S.2d 881, 885 (Sur. Ct. 2011).

111. See Our History, BARNES FounD., https://perma.cc/88ED-JEH5 (last visited Jan. 17, 2021) [hereinafter Our History, BARNES].

112. See Pekarik, supra note 97. 
major collectors," 113 but rather the museum. Put differently, the right approach should encourage leading private collections to become public-serving institutions and reconcile the practices between those collectors and museums. To achieve this, an incentive-based approach is preferable to imposing a legal duty: Using incentives would not create the same tradeoffs that potentially discourage private collecting; it would affirmatively encourage certain positive behavior; and it would not face the same challenges in implementation, because it would invite cooperation from collectors rather than opposition. What is more, as Part II argued, enforcement is unnecessary because many significant collections (and almost all significant artworks) eventually come to reside in the museum. One strong incentive already exists in the tax benefit of establishing a private museum. In an excellent student Note, E. Alex Kirk explains the advantage of creating a private museum, observes how the current doctrine allows for abuse, and recommends reforms that would ensure that private museums provide meaningful public benefits. ${ }^{114}$ This Part outlines a scheme for accrediting significant collections that further the public interest. Because it incorporates additional, public-oriented criteria beyond the requirements for forming a private museum, the accreditation scheme goes farther in terms of promoting the public interest than the private museum solution. Accreditation, in turn, would offer benefits that incentivize collectors to seek it and thereby support the public.

\section{B. ACCREDitation: ReQuirements}

Of course, determining significance raises the same issues regarding establishing a standard and determining who will oversee that standard, as discussed in Part II.B. A particular nuance to accrediting collections rather than individual works requires a rethinking of the standard. Legal standards for determining the cultural significance of individual artworks are incompatible with the idea that a collection might be significant in the aggregate but not with respect to each one of the works encompassed. In fact, as collections grow in size and significance, one would expect the proportion of significant artworks in the collection to diminish; arguably, a "collection" of disparate trophy works is anathema to the concept of a contextual collection.

As a starting point, inspiration for accreditation criteria can be found in the World Heritage Convention's Operational Guidelines, which introduce a "condition of integrity" to assess cultural and natural sites under consideration for the World Heritage List. ${ }^{115}$ Like the NEA's criteria for inclusion on the National Register of Historic Places, the condition of integrity is a good fit for collections because the sites on the World Heritage List are analogous to collections in that they often contain

113. SAX, supra note 8 , at 66 .

114. See Kirk, supra note 2.

115. INTERGOVERNMENTAL COMM. FOR THE PROT. OF THE WORLD CULTURAL \& NAT. HERITAGE, UNESCO, OPERATIONAL GUIDELINES FOR THE IMPLEMENTATION OF THE WORLD HERITAGE CONVENTION, WHC 19/01, ๆๆ 87-90 (2019) [hereinafter WHC OPERATIONAL GuIDELINES]. 
multiple features and derive their significance from those features cumulatively. ${ }^{116}$ Under the Operational Guidelines, "[a]ll properties nominated for inscription on the World Heritage List shall satisfy the conditions of integrity." 117 Integrity embodies two components:

Integrity is a measure of the wholeness and intactness of the natural and/or cultural heritage and its attributes. Examining the conditions of integrity, therefore requires assessing the extent to which the property: a) includes all elements necessary to express its Outstanding Universal Value; b) is of adequate size to ensure the complete representation of the features and processes which convey the property's significance; c) suffers from adverse effects of development and/or neglect. ${ }^{118}$

For cultural heritage in particular, the description of the condition of integrity emphasizes that the property should be well-preserved and protected from deterioration, and that it should contain most if not all of the elements which give the property its distinctive character and value. ${ }^{119}$

The components of wholeness and intactness can be transposed into a framework for assessing the cultural significance of art collections, akin to the "Outstanding Universal Value" of world heritage sites. Wholeness would require that the collection is sufficient to convey that which makes the collection insightful, while intactness would require an assurance from the collector that the works in the collection would be maintained and kept together. For example, to demonstrate wholeness, a collector might provide a scholarly opinion regarding the aims of the collection and how it has realized those aims; to demonstrate intactness, a collector might agree to refrain from conduct that would make the collection susceptible to dissolution. This would include not borrowing against works in the collection, and not using marital funds to pay for, insure, or conserve the work, if doing so would change the character of the artwork from separate property to marital property.

Along with these prerequisites, accreditation could require a set of best practices that includes providing public access, maintaining standards of conservation and security, and other imperatives. Best practices should include registration of all works and their provenance on a database. Such a database would serve two functions: enabling electronic access for educational purposes as well as enhancing the transparency of the collection for governance purposes. If for some reason an artwork left the collection, having up-to-date digital records would facilitate tracking

116. See id. $\uparrow 45$ (defining "cultural heritage" as: "monuments: architectural works, works of monumental sculpture and painting, elements or structures of an archaeological nature, inscriptions, cave dwellings and combinations of features, which are of Outstanding Universal Value from the point of view of history, art or science; groups of buildings: groups of separate or connected buildings which, because of their architecture, their homogeneity or their place in the landscape, are of Outstanding Universal Value from the point of view of history, art or science; sites: works of man or the combined works of nature and man, and areas including archaeological sites which are of Outstanding Universal Value from the historical, aesthetic, ethnological or anthropological points of view.") (emphasis added).

117. WHC OPERATIONAL GUIDELINES, supra note $115, \uparrow 87$.

118. Id. ๆ 88 .

119. Id. $ๆ 89$. 
the work to its next owner. Best practices should also include supporting the public interest in "truth" by holding regular exhibitions and fostering scholarship. By incorporating these practices as criteria, an accreditation system could help guide the norms of collecting more broadly, even though accreditation itself would apply only to significant collections. "Leading" collectors would be defined not only by the nature of their collections, but also by the responsible management of their collections. Highlighting this management would add substance to the notion of the "collector as steward," thereby influencing the behavior of non-accredited collectors who nevertheless wish to be perceived as legitimate.

The composition of the committee that determines significance is less of an issue under accreditation than a forced loan regime because accreditation aligns the interests of collectors and the body representing the public interest. Furthermore, by building registration into the requirements of accreditation, the collector would essentially bear the cost of the evaluation. Because of the opacity of the art world, identifying significant works in an adversarial system like the forced loan regime would be costly even if feasible. A cooperative system like accreditation places the burden of inventorying the collection on the collector and reduces overall costs by eliminating the need to search for works, although an audit might be necessary to confirm the inventory. Since, under this regime, public access to the collection would be a precondition of accreditation rather than a direct imposition on the collector, overreach by the committee that determines significance is unlikely to be a concern. The committee should include museum directors, curators, and scholars, but it should also include market experts like dealers and auction house specialists who can attest to how well the collection meets its objectives in light of what is actually available on the market. What constitutes significance must depend on what can be achieved; for some areas of art, the majority of works are already in the museum, while other areas of art have a strong market which makes collecting comparatively easier.

\section{ACCreditation: Benefits}

Accreditation would offer collectors three key advantages. First, the requirements for accreditation should encompass the requirements for establishing a private museum, so that accredited collections would automatically get tax-exempt status. In this way, all accredited collections would qualify as private museums, though not all private museums might be accredited.

Second, accreditation would confer prestige on the collector. The accrediting body should enhance this factor by promoting social cohesion among the collectors, hosting conferences that invite collectors to discuss and develop best practices.

Third, under accreditation, the AAM and AAMD should relax its restrictions on deaccessioning as between museums and accredited collections. Achieving this might be possible if leading members of the AAM and AAMD also serve on the accrediting committee. Such a rule might disadvantage non-accredited collectors, but it would help serve the public interest by easing the burden that the public trust 
currently imposes on museums, while ensuring that the art remains publicly accessible. Recalling that under the AAM's and AAMD's public trust doctrine, a museum may only deaccession to fund future acquisitions, a reasonable rule might be something along the lines of the following: When deaccessioning to acquire future artworks, the museum must seek the highest price on the market, regardless of whether the buyer is an accredited collector, but the museum may also sell works directly to accredited collectors for other purposes, such as strengthening its endowment or financing a particular initiative. Obviously, from the point of view of the collector, special access to museum-quality work would make accreditation extremely attractive. This rule would also offer overburdened museums a safety valve without compromising the public trust, since the artwork would remain in a publicly accessible collection. And, if the deaccessioned work is one that has been in museum storage and out of public view, selling to an accredited private collection will make it more likely that the work will be publicly shown, which will be an additional benefit to the public.

This rule makes sense in light of the accreditation paradigm, which recognizes the complementary public benefits of private collections and museums. Establishing a civic role for private collections is even more imperative if indeed museums are struggling with the upkeep of their collections, which the evidence suggests. Even if Babcock is correct that museums have been "priced out of the art market," as a policy matter, should the museum be allowed to acquire more works if it cannot adequately care for those which it already owns? Besides, is museum ownership inherently preferable from a public perspective, if the museum keeps the work in storage? These issues indicate that private collections can play an important role not only in ensuring public access, as mentioned in Part II, but also because they can alleviate the pressure on museums. In this regard, the tax advantages of the private museum doctrine helps lower the cost for private collectors to participate in the cultural landscape. A revised deaccessioning rule would make the cultural landscape itself more resilient by spreading artwork, and the concomitant costs of stewarding it, across public museums and accredited private collections.

\section{CONCLUSION}

This Note has explored how the public interest in art accounts for differences between private and museum ownership, the tension between the duty of care and restrictions on deaccessioning in the museum context, why it is necessary to shift from an artwork-focused approach to a collection-focused approach, and how an accreditation system might serve the goal of access as well as additional goals under a collection-focused approach.

It is odd to look at the impending challenges facing ever-expanding museums and conclude that the public interest demands that private collectors provide more artwork to the museum. That would be as much of an imposition on the museum as on the collector. If this burden continues to mount without relief, it is possible that 
museums will be forced to abandon their self-imposed restraints and dispose of work via the market. This would be lamentable from the public point of view.

Arts policy must invite private actors - collectors - to support the public interest in an established, meaningful, and viable way. This opportunity should be met with excitement, not reluctance, because private collections have distinct virtues that make the experience of them especially enriching. Private collections turned public, like the Barnes Foundation and others, are among the country's most cherished and significant arts institutions. Arts policy can incentivize civic-mindedness among collectors and provide guidance on the responsibilities that collecting should entail, responsibilities related to the goals of preservation, access, and truth. To Merryman's goals, one might also add the goals of increased transparency and good governance. Such a policy would harmonize the practices of private and museum ownership, and it would align the norms of private collecting with the public interest, while still preserving the role of the collector and private rights of ownership. 